\title{
PENGARUH KONSEP DIRI DAN MOTIVASI BERPRESTASI TERHADAP HASIL BELAJAR MATEMATIKA SISWA KELAS X (SURVEI PADA SMK SE-KECAMATAN CIRACAS)
}

\author{
SARININGSIH TIORENNA \\ Program Studi Pendidikan Matematika, Fakultas Teknik, Matematika \& IPA \\ Universitas Indraprasta PGRI
}

\begin{abstract}
The purpose of this study was to determine how large a) Effect of self-concept and mathematics student learning outcome 2) The influence of achievement motivation with students 'mathematics learning outcomes 3) Effect of self-concept and achievement motivation of students' mathematics learning outcomes. The research method used is survey method correlational path analysis (path analysis). The sample populations of this study were drawn from affordable with simple random sampling technique, as many as 232 respondents. Instrument used in this study is a questionnaire instrument; to measure the variable self-concept and achievement motivation, as well as a test instrument to measure the outcome variables studied mathematics. After testing, the third such instrument is valid and reliable, so worthy to be used for further research. Furthermore, the data were analyzed descriptively and performed tests that include requirements analysis test for normality and linearity test so that further analysis using statistical parametric. The calculation result shows that the data is normally distributed, as well as the linearity of regression test showed that the linear regression form. The results of hypothesis testing showed that students' self-concept have a significant relationship with students' mathematics learning outcomes, achievement motivation has a significant relationship with learning outcomes and self-concept and mathematics achievement motivation also had a significant relationship with students' mathematics learning outcomes.
\end{abstract}

Key words: self-concept, achievement motivation, the results of studying mathematics.

\section{PENDAHULUAN}

Didalam era globalisasi, setiap orang diharapkan memiliki pendidikan setinggitingginya, minimal sampai tingkat sekolah menengah atas. Pendidikan adalah salah satu sarana untuk mewujudkan pembangunan nasional, diantaranya adalah membentuk manusia-manusia untuk bersikap demokratis dan penuh tenggang rasa serta mengembangkan kreativitas dan tanggung jawab dalam kehidupan bermasyarakat.

Kurikulum KTSP diarahkan untuk mengembangkan pengetahuan, pemahaman, kemampuan, nilai, sikap dan minat peserta didik, agar dapat melakukan sesuatu dalam bentuk kemahiran, ketepatan dan keberhasilan dengan penuh tanggung jawab.

Matematika merupakan salah satu sarana meningkatkan daya nalar siswa, karena didalam matematika terdapat berbagai macam perhitungan-perhitungan seperti penjumlahan, pengurangan, pembagian dan perkalian dan juga dapat meningkatkan kemampuan dalam mengaplikasikan matematika untuk menghadapi tantangan hidup dalam memecahkan masalah karena dalam matematika siswa dilatih untuk dapat berpikir kritis (artinya : kemampuan berpikir untuk memecahkan berbagai masalah yang ditemui dengan analisis yang mendalam dan teliti), berpikir logis (artinya : kemampuan berpikir dengan lebih menggunakan akal budi dan perhitungan-perhitungan yang matang), berpikir sistematis (artinya: kemampuan berpikir secara bertahap dan berkesinambungan, mulai dari hal-hal yang sederhana sampai komplek). 
Namun, banyak anak-anak mengeluhkan bahwa matematika itu sulit akibat akibat nyata yang ditemui adalah kemampuan siswa dalam pelajaran matematika yang relatif rendah. Walaupun matematika itu sulit tetapi dapat diupayakan agar dapat dipahami oleh semua siswa. Matematika tetap diberikan disekolah karena kegunaannya dalam kehidupan sehari-hari, dengan demikian perlu diciptakan suatu situasi belajar dan mengajar yang mendukung tujuan diatas.

Banyak kendala yang dihadapi baik oleh guru matematika maupun oleh siswa itu sendiri dalam proses pembelajaran matematika salah satu kendala yang dihadapi oleh guru matematika antara lain adalah kurangnya kesiapan siswa untuk mengikuti pelajaran matematika, yang mungkin disebabkan oleh rendahnya konsep diri dan kurangnya motivasi siswa untuk berprestasi dalam belajar.

Hal ini bisa dipahami karena masih dianggap matematika menjadi pelajaran yang sulit bagi siswa, sehingga menjadi pelajaran yang tidak disukai dan motivasi siswa untuk mempelajarinya semakin kecil. Bagi siswa yang menganggap matematika menyenangkan maka akan tumbuh konsep dalam diri individu tersebut bahwa ia mampu menyelesaikan persoalan-persoalan dalam matematika sehingga ia akan sangat terpacu dalam menyelesaikan masalah-masalah yang bersifat menantang dalam pelajaran matematika. Sebaliknya, bagi siswa yang matematika sebagai pelajaran yang sulit, maka siswa akan bersikap pesimis dalam menyelesaikan masalah matematika dan akan menanamkan konsep dalam dirinya bahwa ia tidak akan pernah sanggup menyelesaikan persoalanpersoalan yang berkaitan dengan matematika dan menjadi kurang termotivasi untuk mempelajarinya. Sikap-sikap tersebut tentunya akan mempengaruhi hasil yang akan mereka dapat dalam belajar.

Ada beberapa faktor yang mempengaruhi hasil belajar siswa yaitu faktor internal dan eksternal. Faktor internal yaitu faktor yang ada dalam diri siswa meliputi konsep diri, kreatifitas, motivasi, kebiasaan, kecemasan, minat dan sebagainya. Sedangkan faktor eksternal yaitu faktor yang berasal dari luar diri siswa meliputi metode mengajar, media pembelajaran, lingkungan belajar, keadaan social ekonomi, dan sebagainya.

Dalam penelitian ini, peneliti mengkaitkan beberapa faktor internal yang dapat mempengaruhi hasil belajar matematika pada siswa. Faktor-faktor internal tersebut diantaranya adalah konsep diri dan motivasi berprestasi siswa. Faktor konsep diri mempunyai pengaruh yang cukup jelas dalam hal pencapaian hasil belajar. Seseorang yang memiliki konsep diri yang relative tinggi cenderung lebih baik hasil belajarnya dibandingkan dengan seseorang yang memiliki konsep diri relative rendah. Hal ini sesuai dengan apa yang dikemukakan oleh Theodore M. Newcomb, Cs. Bahwa "Sikap seseorang baik positif maupun negative terhadap sesuatu adalah kecenderungan untuk menjadi motivasi dalam hubungan dengan sesuatu itu". Disamping itu juga Theodore M. Newcomb, Cs mengemukakan dalil yang mengatakan bahwa : "Sikap-sikap tidak saja mempengaruhi tingkah laku overt, tetapi juga proses-proses belajar, persepsi dan kognisi”. Konsep diri atau persepsi seseorang tentang dirinya sendiri adalah bagian dari kecakapan personal. Selain itu konsep diri, didalam proses belajar mengajar terbentuk akibat pengalaman pendidikan yang diterima seseorang baik di dalam keluarga, sekolah maupun masyarakat.

Dalam proses belajar mengajar matematika disekolah, apabila seseorang memiliki konsep diri yang positif maka siswa tersebut akan memiliki motivasi berprestasi yang tinggi. Sebaliknya, apabila seseorang memiliki konsep diri yang negative maka siswa tersebut akan memiliki motivasi berprestasi yang rendah sehingga hasil belajar matematikanya pun akan rendah. 
Berdasarkan hal tersebut, maka penulis tertarik mengadakan penelitian untuk mengetahui apakah ada pengaruh konsep diri dan motivasi berprestasi terhadap hasil belajar matematika siswa di SMK.

\section{TINJAUAN PUSTAKA}

\section{Hasil Belajar Matematika}

Belajar merupakan suatu usaha untuk memperoleh hal-hal yang baru dalam pengetahuan, kecakapan, keterampilan tingkah laku dan sebagainya sebagai suatu pengalaman atau sebagai suatu usaha yang tujuannya terarah pada perubahan tingkah laku yang dapat diamati.

Menurut Oemar Hamalik (2003:30) dalam buku Proses belajar mengajar mengatakan bahwa bukti seseorang telah belajar adalah terjadinya perubahan tingkah laku pada orang tersebut. Misalnya dari tidak tahu menjadi tahu, dari tidak mengerti menjadi mengerti. Tingkah laku memiliki unsur subjektif dan motoris. Unsur subjektif adalah unsur rohani, sedangkan unsur motoris adalah unsur jasmani. Seseorang sedang berpikir dapat dilihat dari raut mukanya, sikapnya dalam rohaninya tidak bisa dilihat.

Berdasarkan pemaparan diatas dapat disimpulkan bahwa belajar adalah suatu kegiatan yang dilakukan seseorang untuk memperoleh hasil yaitu perubahan-perubahan dalam interaksi aktif dengan lingkungannya yang menghasilkan perubahan bersifat konstan atau tetap.

Untuk mengatakan bahwa suatu proses hasil belajar mengajar berhasil, dapat diketahui apabila kompetensi dasar dapat dicapai. Indikator yang dijadikan tolak ukur dalam menyatakan bahwa suatu proses hasil belajar mengajar dapat berhasil apabila daya serap terhadap bahan pelajaran yang diajarkan mencapai prestasi tinggi,baik secara individu maupun kelompok. Kemudian perilaku yang digariskan dalam tujuan pengajaran telah dicapai baik individu maupun kelompok. Ahmadi (2004:70) menyatakan bahwa hasil belajar adalah hasil-hasil yang telah dicapai oleh siswa dari waktu ke waktu dan ini merupakan informasi yang diperoleh melalui evaluasi yang akan dijadikan sebagai titik tolak untuk memperbaiki dan meningkatkan hasil belajar mengajar dan selanjutnya.

Arifin (2004:74) dalam bukunya "Evaluasi Instruksional" menyatakan bahwa prestasi belajar semakin terasa penting untuk dipermasalahkan, karena mempunyai beberapa fungsi utama antara lain :

a. Prestasi belajar sebagai indikator kualitas dan kuantitas pengetahuan yang telah dikuasai anak didik.

b. Prestasi belajar sebagai bahan informasi dalam inovasi pendidikan. Asumsinya bahwa prestasi belajar dapat dijadikan pendorong bagi anak didik dalam meningkatkan ilmu pengetahuan dan teknologi dan berperan sebagai umpan balik dalam meningkatkan mutu pendidikan.

c. Prestasi belajar sebagai indicator intern dan ekstern dari suatu institusi pendidikan

Menurut Erman Suherman (2003:17) didefinisikan bahwa matematika adalah pola berpikir, pola mengorganisasikan, pembuktian yang logik, matematika itu adalah bahasa yang menggunakan istilah yang didefinisikan dengan cermat, jelas, dan akurat, representasinya dengan simbol dan padat, lebih berupa bahasa simbol mengenai ide daripada mengenai bunyi. Hudojo (2008:3) menyatakan bahwa matematika berkenaan dengan ide-ide, struktur-struktur dan hubungan-hubungannya yang diatur secara logik sehingga matematika itu berkaitan dengan konsep-konsep abstrak. Lebih lanjut dalam buku landasan matematika, Andi hakim nasution (2008:12) mengemukakan bahwa: "istilah matematika berasal dari kata yunani "Mathein"atau "Manthein" yang artinya "Mempelajari". Mungkin juga kata itu erat hubungannya dengan kata sangsekerta "Midha" atau "Widya" yang artinya ialah "Kepandaian", "Ketahuan", "Intelegensi". 
Dari pemaparan diatas dapat disimpulkan bahwa Hasil belajar matematika adalah tingkat kemampuan yang dimiliki siswa setelah diberikan tes hasil belajar matematika.

\section{Konsep Diri}

Sejak kecil individu telah dipengaruhi dan dibentuk oleh berbagai pengalaman yang dijumpai dalam hubungannya dengan individu lain, terutama dengan orang-orang terdekat, maupun yang didapatkan dalam peristiwa-peristiwa kehidupan. Sejarah hidup individu dari masa lalu dapat membuat dirinya memandang diri lebih baik atau lebih buruk dari kenyataan sebenarnya. Dalam psikologi secara umum istilah tersebut merujuk pada komposisi ide, perasaan dan sikap orang mengenai dirinya sendiri. Atau lebih luas lagi persepsi seorang mengenai dirinya sendiri. (Wolfolk Anita E \& Nicol, 2004;121)

Menurut Puspasari Amaryllia (2007:1) dalam bukunya "Mengukur konsep diri anak" dikatakan bahwa: Pada dasarnya apa yang dipercayai seseorang tentang dirinya sendiri akan sangat mempengaruhi prilaku orang tersebut. Jika seseorang percaya atau meyakini bahwa dia jujur, maka orang itu akan cenderung bertindak sesuai dengan apa yang diyakininya. Jika seseorang merasa bahwa ia mampu efektif dengan orang lain, maka orang tersebut dapat berperan sebagai pemimpin, dan sebaliknya tidak dapat berperan sebagai pemimpin jika meyakini dirinya tidak efektif mempengaruhi orang lain. Pemahaman mengenai konsep diri merupakan hasil dari bagaimana kita melakukan proses mengenali diri sendiri.

Berdasarkan pendapat ahli diatas, maka dapat diambil kesimpulan bahwa konsep diri merupakan suatu hal yang sangat penting dalam pengintegrasian kepribadian, memotivasi tingkah laku sehingga pada akhirnya akan tercapainya kesehatan mental.

Menurut Parulian Hutapea dan Nuriana Thoha (2008: 30), Konsep diri (self concept) merupakan sikap atau nilai individu. Nilai individu mempunyai sifat reaktif yang dapat memprediksi apa yang akan dilakukan oleh seseorang dalam waktu singkat. Konsep diri dipengaruhi oleh nilai-nilai yang dimiliki oleh seseorang yang diperolehnya sejak kecil sampai saat tertentu. Konsep diri menunjukkan bagaimana seseorang melihat dirinya sendiri atau sesuatu. Konsep diri ini mempengaruhi etika, cara pandang atau pengertian seseorang tentang sesuatu. Disisi lain, Djadi (2008: 129) mengemukakan bahwa "Konsep diri adalah pandangan seseorang tentang dirinya sendiri yang menyangkut apa yang ia ketahui dan rasakan tentang prilaku, isi pikiran dan perasaannya serta bagaimana prilakunya tesebut berpengaruh terhadap orang lain. "Dengan demikian konsep diri merupakan kesadaran dan evaluasi individu terhadap dirinya sendiri mengenai pikiran dengan berbagai persepsi tentang dirinya sendiri atau dengan kata lain bahwa sumber daya utama konsep diri berasal dari dirinya sendiri. Dalam hal ini, dirinya sendiri yang aktif untuk terus meneliti dengan mengevaluasi mengenai keadaan dan kemampuan diri sendiri secara lengkap.

Smith dalam Djumari Mordapi (2004: 9), sedikit berbeda dengan pendapat sebelumnya. Dengan mengungkapkan bahwa: Konsep diri adalah evaluasi yang dilakukan individu yang bersangkutan terhadap kemampuan dan kelemahan yang dimilikinya. Target, arah dan intensitas konsep diri pada dasarnya seperti ranah evektif yang lain. Target konsep diri biasanya orang, tetapi bisa juga institusi seperti sekolah. Arah konsep diri bisa positif atau negative, dan intensitasnya bisa dinyatakan dalam suatu daerah kontinu yaitu mulai dari yang rendah sampai yang tinggi. Meskipun konsep diri adalah milik seseorang secara individual, ternyata konsep diri juga terbentuk melalui interaksi dengan orang lain dan mengacu pada bagaimana pendapat orang tentang dirinya. 


\section{Motivasi Berprestasi}

Setiap tindakan manusia selalu didorong oleh faktor-faktor tertentu sehingga terjadi tingkah laku atau perbuatan. Faktor pendorong ini di sebut motif. Motif adalah suatu alasan atau dorongan yang menyebabkan individu berbuat sesuatu atau melakukan tindakan tertentu. Motif-motif tersebut pada saat tertentu akan menjadi aktif apabila kebutuhan untuk mencapai tujuan sangat dirasakan (Ninawati,2002:124).

Menurut Robin (2002 : 36), mendefinisikan motivasi sebagai suatu kemauan untuk menggunakan segala upaya yang paling tinggi dari tujuan organisasi disesuaikan dengan kemampuan yang diupayakan untuk memenuhi beberapa kebutuhan individu.

Menurut Djiwandono (2008 : 35), Motivasi adalah salah satu persyaratan yang amat penting dalam bekerja. Mc Donald yang dikutip oleh Wasty Soemanto (2006 : 11) motivasi didefinisikan sebagai suatu perubahan tenaga di dalam diri seseorang yang ditandai dengan dorongan efektif dan reaksi - reaksi dalam usaha mencapai tujuan. Definisi ini berisi tiga hal, yaitu : (a) Motivasi di mulai dengan suatu perubahan tenaga dalam diri seseorang, (b) Motivasi itu ditandai dengan dorongan efektiv, (c) Motivasi ditandai oleh reaksi - reaksi mencapai tujuan.

Sementara itu menurut Sartain dalam Purwanto (2007 : 232), Motivasi adalah suatu pernyataan yang kompleks didalam suatu organisme yang mengarahkan tingkah laku terhadap suatu tujuan (Goal) atau perangsang (Insentive).

Menurut Mc Clelland dalam Djiwandono (2008 : 305), Motivasi berprestasi adalah dimana seseorang cenderung berjuang untuk mencapai sukses atau memilih suatu kegiatan yang berorientasi untuk tujuan sukses atau gagal.

Dengan demikian motivasi berprestasi bersumber dari dalam individu dan bukan dari diri orang lain, sehingga dapat tercapai suatu keberhasilan dalam belajar. Motivasi berprestasi sangat penting perannya dalam pencapaian suatu keberhasilan karena tercapai suatu keberhasilan seseorang disebabkan adanya motivasi dari diri sendiri sehingga tercapai hasil belajar yang baik.

Menurut Sri Esti (2009 : 329), Motivasi mempunyai intensitas dan arah (direction). Intensitas dari motivasi yang digunakan untuk satu kegiatan mungkin tergantung pada besarnya intensitas itu dari pada besarnya direction. Jika seseorang hanya mempunyai cukup waktu dan uang untuk melihat sepak bola, notivasi untuk kegiatan ini secara kuat dipengaruhi oleh intensitas dari pada direction. Banyak faktor-faktor yang dapat mempergaruhi motivasi berprestasi seseorang. Cara-cara orang tua dalam mendidik anak sangat berpengaruh terhadap motivasi berprestasi yang dimiliki oleh anak. orang tua yang memiliki anak yang motivasi berprestasi tinggi adalah orang tua yang memberikan dorongan kepada anak untuk berusaha pada tugas-tugas yang sulit, selalu memberikan pujian atau hadiah ketika anak telah menyelesaikan suatu tugas, mendorong anak untuk menemukan cara terbaik dalam mendapatkan kesuksesan dan melarang anak untuk selalu mengeluh tentang kegagalan serta menyarankan anaknya untuk menyelesaikan sesuatu yang menantang lagi.

Selanjutnya Fernald (1999:80) mengungkapkan terdapat 4 faktor yang berpengaruh terhadap motivasi berprestasi bagi seseorang yaitu :

1. Pengaruh keluarga dan kebudayaan (family and cultural influences)

Besarnya kebebasan yang diberikan orang tua kepada anaknya, jenis pekerjaan orang tua dan jumlah serta urutan anak dalam suatu keluarga memiliki pengaruh yang sangat besar dalam perkembangan motivasi berprestasi. Produk-produk kebudayaan pada suatu Negara seperti cerita rakyat sering mengandung tema-tema prestasi yang bisa meningkatkan semangat warga negaranya.

2. Peranan dari konsep diri (role of self concept) 
Konsep diri merupakan bagaimana seseorang berpikir mengenai dirinya sendiri. Apabila individu percaya bahwa dirinya mampu untuk melakukan sesuatu maka individu akan termotivasi untuk melakukan hal tersebut sehingga berpengaruh dalam bertingkah laku.

3. Pengaruh dari peran jenis kelamin (influence of sex roles)

Prestasi yang tinggi biasanya diidentikan dengan maskulinitas, sehingga banyak para wanita belajar tidak maksimal khususnya jika wanita tersebut berada diantara pria. pada wanita terdapat kecenderungan takut akan kesuksesan (fear of success) yang artinya pada wanita terdapat kekhawatiran bahwa dirinya akan ditolak oleh masyarakat apabila dirinya memperoleh kesuksesan, namun sampai saat ini konsep fear of success masih diperdebatkan. Perbedaan jenis kelamim pada pria dan wanita lebih disebabkan karena faktor budaya bukan genetic.

4. Pengakuan dan prestasi (recognition and achievement) Individu akan termotivasi untuk bekerja keras jika dirinya merasa diperdulikan oleh orang lain.

Setiap individu yang telah terpenuhi kebutuhan pokoknya pastilah sedikit banyak memiliki motivasi berprestasi. Namun yang membedakan antara individu yang memiliki motivasi berprestasi yang tinggi dan yang rendah adalah keinginan dirinya untuk dapat menyelesaikan sesuatu dengan lebih baik.

Ciri-ciri orang yang memiliki motivasi berprestasi yang tinggi adalah :

1. Berprestasi yang dihubungkan dengan seperangkat standar. Seperangkat standar tersebut bisa dihubungkan dengan prestasi orang lain, prestasi diri sendiri yang lampau serta tugas yang harus dilakukannya

2. Memiliki tanggung jawab pribadi terhadap kegiatan-kegiatan yang dilakukan.

3. Adanya kebutuhan untuk mendapatkan umpan balik atas pekerjaan yang dilakukannya sehingga dapat diketahui dengan cepat hasil yang diperoleh dari kegiatannya lebih baik atau lebih buruk.

4. Menghindarkan tugas-tugas yang sulit atau terlalu mudah, tetapi akan memilih tugastugas yang tingkat kesukarannya sedang.

5. Inovatif yaitu dalam melakukan suatu pekerjaan dilakukan dengan cara yang berbeda, efisien dan lebih baik daripada sebelumnya. Hal ini dilakukan agar individu mendapatkan cita-cita yang lebih menguntungkan dalam pencapaian tujuan.

6. Tidak menyukai keberhasilan yang bersifat kebetulan atau karena tindakan orang lain dan ingin merasakan sukses atau kegagalan disebabkan oleh tindakan individu itu sendiri.

Berdasarkan pemaparan diatas, dapat kesimpulan bahwa motivasi berprestasi adalah dorongan yang ada pada individu untuk mengungguli, mendapatkan prestasi yang dihubungkan dengan seperangkat standar dan berusaha mendapatkan kesuksesan atas kegiatan yang dilakukannya. Individu yang memiliki motivasi berprestasi tinggi adalah individu yang memiliki standar berprestasi, memiliki tanggung jawab pribadi atas kegiatan yang dilakukannya, individu lebih suka bekerja pada situasi dimana dirinya mendapatkan umpan balik sehinggga dapat diketahui seberapa baik tugas yang telah dilakukannya, individu tidak menyukai keberhasilan yang bersifat kebetulan atau karena tindakan orang lain, individu lebih suka bekerja pada tugas yang tingkat kesulitannya menengah dan realistis dalam pencapaian tujuannya, individu bersifat inovatif dimana dalam melakukan suatu tugas dilakukan dengan cara yang berbeda, efisien dan lebih baik daripada sebelumnya, serta individu akan merasa puas serta menerima kegagalan atas tugas-tugas yang dilakukannya. 


\section{METODE}

Penelitian dilakukan di SMK-SMK se Kecamatan Ciracas, pada semester kedua tahun pelajaran 2009/2010. Dibawah ini terdapat tabel nama-nama SMK yang ada di Kecamatan Ciracas (Sumber: bagian sistem informasi biro perencanaan dan KLN Kemendiknas).

Tabel 1. Nama-nama SMK di Kecamatan Ciracas

\begin{tabular}{|c|c|c|l|}
\hline No. & $\begin{array}{c}\text { NPSN (Nomor } \\
\text { Pokok Sekolah } \\
\text { Nasional) }\end{array}$ & Nama SMK & \multicolumn{1}{|c|}{ Alamat } \\
\hline 1. & 20103764 & SMK Mahadhika 1 & Jalan Raya centex no 29-31 \\
\hline 2 & 20103761 & SMK Mahadhika 3 & Jalan raya centex no 29-31 \\
\hline 3. & 20103541 & SMK PKP 1 & $\begin{array}{l}\text { Jalan Raya PKP kelapa dua } \\
\text { wetan }\end{array}$ \\
\hline 4. & 20103540 & SMK PKP 3 & $\begin{array}{l}\text { Jalan Raya PKP kelapa dua } \\
\text { wetan }\end{array}$ \\
\hline 5. & 20103656 & SMK Era Pembangunan & Jalan Usman no. 71 \\
\hline 6 & 20103643 & SMK insan Teknologi & Jalan Cibubur IV no. 29 \\
\hline 7 & 20103267 & SMK Bina Dharma & Jalan Raya Ciracas n0. 39 \\
\hline 8 & 20103264 & SMK Al-Wahyu & Jalan Madrasah No.24 \\
\hline 9 & 20103657 & SMK Eka Paksi Jakarta & Jalan Mualim Aminuddin \\
\hline 10 & 20103640 & SMK PGRI 20 & $\begin{array}{l}\text { Jalan Haji Abdurrachman no. } \\
54\end{array}$ \\
\hline 11 & 20103731 & SMK Otomindo & Jalan Belly/Mekar V \\
\hline 12 & 20103780 & SMKN 52 & Jalan Taruna jaya PUSDIKA \\
\hline & & & \\
\hline
\end{tabular}

Pendekatan penelitian yang di gunakan adalah penelitian kuantitatif dengan teknik penelitian survey korelasional. Teknik analisis statistik yang digunakan pada penelitian ini adalah Path analysis (analisis jalur). Tujuan Analisis jalur adalah untuk menganalisis hubungan kausal antar variabel dengan tujuan untuk mengetahui pengaruh langsung dan tidak langsung beberapa variabel penyebab terhadap sebuah variabel akibat. (Kusnendi,2005:4). Variabel yang diteliti pada penelitian ini adalah:

1. Variabel bebas (Eksogen):

- Konsep diri siswa terhadap kemampuannya dalam Matematika

- Motivasi Berprestasi siswa pada pelajaran Matematika

2. Variabel terikat (Endogen) : Hasil belajar matematika siswa. 


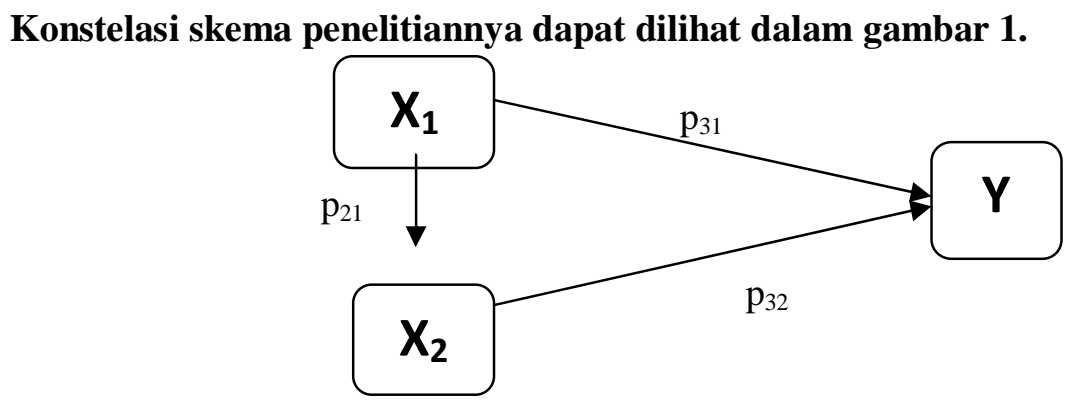

Gambar 1. Desain Penelitian

Populasi target pada penelitian ini adalah seluruh siswa kelas X SMK seKecamatan Ciracas. Populasi terjangkau pada penelitian ini adalah siswa SMK seKecamatan Ciracas kelas X pada semester kedua tahun pelajaran 2009/2010. Dalam penelitian ini tidak semua siswa berhak menjadi anggota sampel penelitian. Yang menjadi anggota sampel penelitian dari 5 SMK hanya 1 atau 2 kelas saja. Diharapkan melalui pengambilan sampel ini, data informasi yang diharapkan dapat terjaring secara obyektif dan komprehensif dan dapat mewakili karakteristik populasi penelitian.

Di dalam penelitian ini, untuk mendapatkan data tentang konsep diri dan motivasi berprestasi siswa pada pelajaran matematika digunakan instrumen skala sikap yang peneliti buat sendiri berdasarkan karakteristik dari masing-masing variabel bebas, yaitu konsep diri dan motivasi berprestasi siswa pada pelajaran matematika. Sedangkan data tentang hasil belajar kognitif matematika siswa diambil dari nilai ulangan semester matematika pada semester kedua tahun pelajaran 2009/2010.

Tehnik pengumpulan data terdiri dari 2 instrument yang berbentuk angket yaitu angket untuk mengumpulkan data tentang konsep diri dan motivasi berprestasi siswa. Untuk data hasil belajar matematika siswa adalah nilai ujian matematika akhir semester 2 Tahun Pelajaran 2009/2010.

Data diolah dengan menggunakan analisis statistik deskriptif untuk menyajikan data masing-masing variabel. Statistik deskriptif yang digunakan adalah persentase dan distribusi frekuensi yaitu nilai rata-rata, standart deviasi dan histogram. Statistik inferensial yang digunakan untuk menguji hipotesis penelitian adalah metode statistik analisis jalur (path analysis). Dalam penelitian ini analisis jalur digunakan untuk mengetahui pengaruh langsung dan tak langsung antara konsep diri, motivasi berprestasi dan hasil belajar. Dalam model analisis jalur dikenal dua tipe variabel yaitu variabel eksogen dan endogen. Variabel eksogen adalah variabel yang menyebabkan dan memberikan efek langsung maupun tak langsung terhadap variabel endogen. Variabel endogen dapat mempengaruhi variabel endogen lainnya.

Sesuai dengan kerangka berfikir yang telah dikembangkan maka variabel endogen dalam penelitian ini adalah konsep diri dan motivasi berprestasi, sedangkan variabel endogen yang berposisi 'prediktor' adalah hasil belajar siswa.

Sebelum menguji hipotesis penelitian, terlebih dahulu dilakukan uji persyaratan analisis yang meliputi uji normalitas dan uji linearitas. Setelah itu dilakukan Uji Multikolinearitas dimaksudkan untuk mengetahui apakah terdapat korelasi antar variabel independen. Dalam model regresi seharusnya tidak memiliki pengaruh yang multikolinearitas. Uji mulitikolinearitas dihitung berdasarkan hasil tabel coefficients, dapat dilihat pada output coefficients model. Variabel penelitian dikatakan tidak memiliki gejala multikolinearitas jika nilai VIF $<10$ 


\section{HASIL DAN PEMBAHASAN}

Persyaratan dalam menganalisis data yang pertama dilakukan adalah uji normalitas. Uji normalitas ini dilakukan untuk mengetahui normal tidaknya distribusi data yang akan dianalisis. Data tersebut meliputi variabel motivasi berprestasi dan konsep diri siswa dan hasil belajar siswa. Dari hasil SPSS dapat disimpulkan bahwa keseluruhan data berasal dari populasi yang berdistribusi NORMAL dan LINEAR. Dari uji multikolinearitas disimpulkan bahwa data memenuhi persyaratan asumsi klasik.. Besarnya pengaruh variabel eksogen terhadap variabel endogen didapat yaitu: (1) besarnya pengaruh langsung variabel $\mathrm{X}_{1}$ terhadap $\mathrm{Y}$ yaitu $=0,01138=1,138 \%$, besarnya pengaruh tidak langsung variabel $\mathrm{X}_{1}$ terhadap $\mathrm{Y}$ melalui $\mathrm{X}_{2}$ yaitu $=0,00863=0,0863 \%$, sehingga besarnya pengaruh total variabel $X_{1}$ terhadap $Y$ yaitu $=0,0200=2,00 \%$. (2) besarnya pengaruh langsung variabel $\mathrm{X}_{2}$ terhadap $\mathrm{Y}$ yaitu $=0,01510=1,510 \%$ dan (3) besarnya pengaruh langsung variabel $X_{1}$ terhadap $X_{2}$ yaitu $=0,433=43,3 \%$. Secara bersama-sama konsep diri dan motivasi berprestasi mempengaruhi hasil belajar matematika siswa sebesar $1,510 \%+43,3 \%=44,81 \%$. Sedangkan koofisien determinasi diperoleh 0,0939 $=9,39 \%$ yang artinya sebanyak $9,39 \%$ variasi konsep diri terhadap motivasi berprestasi siswa memberikan kontribusi pada variasi hasil belajar matematika siswa. Untuk koofisien residu diperoleh $0,9953=99,53 \%$ dan besarnya pengaruh variabel residu terhadap variabel hasil belajar matematika siswa yaitu sebesar 99,53. Sehingga sangat besar variabel residu memberikan pengaruhnya kepada variabel hasil belajar matematika siswa. Selanjutnya dilakukan pengujian koofisien jalur, pengujian secara keseluruhan terlebih dahulu diperoleh $\mathrm{f}_{\text {hitung }}=11,8657$ dan nilai $\mathrm{p}(\mathrm{sig})=0,000$ yang berasal dari tabel ANOVA dengan Kriteria Tolak $\mathrm{H}_{\mathrm{o}}$ jika nilai $\mathrm{P}(\mathrm{sig})<0,05$, maka kesimpulannya pengujian koofisien jalur secara individual dapat dilakukan dan diagram jalur penelitian secara keseluruhan dapat digunakan. Kemudian dilakukan pengujian hipotesi untuk mengetahui kebermaknaan koofisien jalur secara individual.

Berdasarkan data penelitian tentang pengaruh konsep diri siswa dan motivasi berprestasi terhadap hasil belajar matematika dinyatakan sebagai berikut:

\section{Pengaruh langsung konsep diri siswa terhadap hasil belajar matematika}

Pengujian hipotesis 1 menggunakan uji t. Berdasarkan hasil perhitungan diperoleh $\mathrm{t}_{\text {hitung }}=1,2778$ dan $\mathrm{t}_{\text {tabel }}=\mathrm{t}_{(1-\alpha ; n-\mathrm{k}-1)}=\mathrm{t}_{(0,5 ; 229)}=0,674$. Karena $\mathrm{t}_{\text {hitung }}>\mathrm{t}_{\text {tabel }}$ maka Tolak $\mathrm{H}_{0}$ yang artinya koofisien jalur $\mathrm{p}_{31}$ signifikan. Sehingga koofisien jalur $\mathrm{p}_{31}$ secara stastistik bermakna. Hasil penelitian ini sejalan dengan pendapat Atwater (1987;180) yang mengatakan bahwa konsep diri adalah keseluruhan gambaran diri, yang meliputi persepsi seseorang tentang diri, perasaan,keyakinan dan nilai-nilai yang berhubungan dengan dirinya. Seorang siswa yang memiliki gambaran positif tentang dirinya akan mempengaruhi keyakinannya akan kemampuannya dalam mengerjakan masalah-masalah dalam matematika. Sehingga semakin baik seseorang memandang dirinya maka hasil belajar matematikanya pun akan tinggi.

Melalui data hasil penelitian juga dapat dijelaskan bahwa konsep diri siswa memiliki pengaruh yang langsung terhadap hasil belajar matematika siswa. Melalui persamaan regresi $\hat{Y}=2,0339+0,013 \mathrm{X}_{1}$. Persamaan tersebut menginformasikan bahwa setiap peningkatan konsep diri sebesar satu satuan, maka secara bersamaan akan mempengaruhi perolehan hasil belajar matematika sebesar 0,013 dengan konstanta 2,0339 .

Konsep diri siswa memiliki peran yang signifikan terhadap hasil belajar matematika, hal ini di mungkinkan karena $1,138 \%$ hasil belajar matematika dipengaruhi oleh konsep diri masing-masing peserta didik. Semakin tinggi konsep diri siswa akan semakin tinggi pula hasil belajar matematikanya. Temuan tersebut sesuai dengan temuan 
penelitian yang dilakukan sebelumnya dengan kesimpulan bahwa, setiap individu dilahirkan dengan suatu organism yang disebut konsep diri yang bersumber dari dalam diri siswa dan juga lingkungannya.

Sejak kecil individu telah dipengaruhi dan dibentuk oleh berbagai pengalaman yang dijumpai dalam hubungannya dengan individu lain, terutama dengan orang-orang terdekat, maupun yang didapatkan dalam peristiwa-peristiwa kehidupan. Sejarah hidup individu dari masa lalu dapat membuat dirinya memandang diri lebih baik atau lebih buruk dari kenyataan sebenarnya. Dalam psikologi secara umum istilah tersebut merujuk pada komposisi ide, perasaan dan sikap orang mengenai dirinya sendiri. Atau lebih luas lagi persepsi seorang mengenai dirinya sendiri.

Pengharapan mengenai diri akan menentukan bagaimana individu akan bertindak dalam hidup. Apabila seseorang individu berpikir bahwa dirinya bisa, maka individu tersebut cenderung sukses. Dan bila individu tersebut berpikir bahwa dirinya akan gagal, maka sebenarnya dirinya telah menyiapkan diri untuk gagal. Jadi bisa dikatakan bahwa konsep diri merupakan bagian diri yang mempengaruhi setiap aspek pengalaman baik itu pikiran, perasaan, persepsi dan tingkah laku individu. Penglihatan individu atas diri sendiri disebut gambaran diri (self image). Perasaan individu atas dirinya sendiri merupakan penilaian individu atas dirinya sendiri (self evaluation). Harapan individu atas dirinya sendiri menjadi cita-cita diri (self idea).

Dalam perkembangannya Konsep diri terbagi menjadi dua, yaitu konsep diri positif dan konsep diri negatif.

1. Konsep diri positif

Konsep diri positif lebih kepada penerimaan diri bukan sebagai suatu kebanggaan yang besar tentang diri. Konsep diri yang positif bersifat stabil dan bervariasi. Individu yang memiliki konsep diri positif adalah individu yang tahu betul tentang dirinya, dapat memahami dan menerima sejumlah fakta yang bermacam-macam tentang dirinya sendiri, evaluasi terhadap dirinya sendiri menjadi positif dan dapat menerima keberadaan orang lain. Individu yang memiliki konsep diri positif akan merancang tujuan-tujuan yang sesuai dengan realitas, yaitu tujuan yang memiliki kemungkinan besar untuk dapat dicapai, mampu menghadapi kehidupan didepannya serta menganggap bahwa hidup adalah suatu proses pemenuan.

Singkatnya, individu memiliki konsep diri positif adalah individu yang tahu betul siapa dirinya sehingga dirinya menerima segala kelebihan dan kekurangan, evaluasi terhadap dirinya menjadi lebih positif serta mampu merancang tujuan-tujuan yang sesuai dengan realitas.

2. Konsep diri negatif

Konsep diri negatif terbagi lagi menjadi dua tipe, yaitu :

a. Pandangan individu tentang dirinya sendiri benar-benar tidak teratur, tidak memiliki perasaan stabil dan keutuhan diri. Individu tersebut benar-benar tidak tahu siapa dirinya, kekuatan dan kelemahannya atu yang dihargai dalam kehidupannya.

b. Pandangan tentang dirinya sendiri terlalu stabil dan teratur. Hal ini bisa terjadi karena individu dididik dengan cara yang sangat keras, sehingga menciptakan citra diri yang tidak mengizinkan adanya penyimpangan dari seperangkat hokum yang dalam pikirannya merupakan cara hidup yang tepat.

Dengan memahami peranan konsep diri dalam peningakatan hasil belajar matematika siswa maka semua pihak yang berperan seperti : keluarga, guru, masyarakat harus mengerti dan mengusahakan siswa untuk memiliki konsep diri yang positif. Siswa yang memiliki konsep diri yang positif akan memandang dirinya memiliki kemampuan untuk menyelesaikan soal-soal yang sulit dan merasa bahwa itu adalah hal yang menyenangkan 
dan sangat mempengaruhi hasil belajar siswa. Sedangkan siswa yang memiliki konsep diri yang negatif akan memandang dirinya tidak memiliki kemampuan untuk dapat menyelesaikan soal-soal matematika dan akhirnya hasil belajar yang dicapai tidak maksimal.

\section{Pengaruh langsung motivasi berprestasi terhadap hasil belajar matematika}

Pengujian hipotesis 2 menggunakan uji t. Berdasarkan hasil perhitungan diperoleh $\mathrm{t}_{\text {hitung }}=1,4719$ dan $\mathrm{t}_{\text {tabel }}=\mathrm{t}_{(1-\alpha ; n-\mathrm{k}-1)}=\mathrm{t}_{(0,5 ; 229)}=0,674$. Karena $\mathrm{t}_{\text {hitung }}>\mathrm{t}_{\text {tabel }}$ maka Tolak $\mathrm{H}_{0}$ yang artinya koofisien jalur $\mathrm{p}_{32}$ signifikan. Sehingga koofisien jalur $\mathrm{p}_{32}$ secara stastistik bermakna.

Hasil penelitian ini sejalan dengan pendapat McClelland dan Atkinson (1948;354) yang menyatakan bahwa motivasi yang paling penting untuk psikologi pendidikan adalah motivasi berprestasi, dimana seseorang cenderung berjuang untuk mencapai sukses atau memilih suatu kegiatan yang berorientasi untuk tujuan sukses atau gagal. Sehingga tidak mengherankan siswa yang motivasinya untuk berprestasi tinggi cenderung sukses dalam melakukan tugas-tugas disekolah (Wendth,1955; French dan Thomas, 1958; Kestenbaum,1970). Dengan demikian dapat disimpulkan bahwa siswa yang memiliki motivasi untuk berprestasi tinggi, maka hasil belajar matematikanya pun tinggi.

Motivasi berprestasi siswa dapat ditimbulkan dengan cara memberikan stimulus yang berpangkal pada kebutuhan siswa. Siswa yang memiliki motivasi selalu unggul dan berprestasi dalam proses belajar mengajar tidak merasa takut gagal melainkan selalu berusaha untuk memperbaiki kesalahannya sehingga dapat meningkatkan hasil belajar matematikanya.

Kebutuhan dasar manusia awalnya berhubungan dengan fisiologis, jika kebutuhan ini sudah terpenuhi maka kebutuhan yang mendesak adalah kebutuhan akan rasa aman dan perlindungan. Apabila ini sudah terpenuhi maka kebutuhan berikutnya yang harus dipenuhi adalah kebutuhan social dan jika sudah terpenuhi maka kebutuhan berikutnya yang mendesak untuk dipenuhi adalah kebutuhan untuk dihargai, kebutuhan untuk berprestasi dan kebutuhan tertinggi yang mendesak dan harus dipenuhi setelah kebutuhan sebelumnya sudah terpenuhi adalah kebutuhan aktualisasi diri misalnya kebutuhan untuk menjadi terkenal. Jadi, menurut kebutuhan maslow ini bahwa manusia melakukan tindakan atau perbuatan karena dorongan-dorongan untuk memenuhi kebutuhannya. Kebutuhannyalah yang memotivasi untuk melakukan aktivitas-aktivitas manusia. Berdasarkan penjelasan diatas dapat ditarik kesimpulan bahwa motivasi adalah serangkaian usaha pada kondisi tertentu sehingga seorang mau melakukan sesuatu untuk memenuhi kebutuhannya. Motivasi merupakan motif yang sudah menjadi aktif. Jadi dapat disimpulkan bahwa motivasi berprestasi adalah serangkaian usaha pada kondisikondisi tertentu sehingga seseorang mau melakukan tindakan atau aktivitas menggumpulkan sejumlah pengetahuan yang menyebabkan perubahan tingkah laku.

Siswa yang memiliki motivasi berprestasi mempunyai harapan untuk berhasil, memiliki sikap positif terhadap pencapaian suatu tujuan dan tidak terlalu memikirkan kemungkinan-kemungkinan untuk gagal. Siswa yang memiliki motivasi berprestasi dalam belajar akan mengikuti kegiatan belajar dengan penuh keyakinan untuk berhasil karena motivasi berprestasi akan mendukung faktor-faktor lain dalam pencapaian tugas-tugas belajar. Seringkali peserta didik yang cerdas akan tampak kelihatan bodoh karena tidak memiliki motivasi untuk berprestasi dalam belajar. Betapapun baiknya potensi siswa dan lengkapnya sarana belajar jika tidak disertai dengan motivasi maka proses belajar mengajar tidak akan berjalan dengan optimal.

Keberhasilan pencapaian tugas belajar ditentukan proses yang ada didalamnya yaitu proses belajar mengajar dikelas. Jika prosesnya berjalan optimal maka hasilnya pun 
akan optimal. Hal itu mungkin akan terjadi apabila didalam diri peserta didik ada motivasi untuk berprestasi dalam belajar. Karena siswa yang memiliki motivasi berprestasi yang rendah akan menampakkan kemalasan yang dapat mempengaruhi hasil belajarnya.

Siswa yang memiliki motivasi berprestasi tinggi dalam belajar akan menampakkan minat yang besar dan perhatian yang penuh terhadap tugas-tugas belajar, sebaliknya siswa yang memiliki motivasi berprestasi yang rendah akan berusaha menghindar dalam pemenuhan tugas-tugas belajar. Dan semua tindakan yang lahir dari motivasi berprestasi dalam diri siswa secara langsung akan berdampak terhadap prestasi akademis nya di sekolah.

\section{Pengaruh langsung konsep diri terhadap motivasi berprestasi}

Pengujian hipotesis 3 menggunakan uji t. Berdasarkan hasil perhitungan diperoleh $\mathrm{t}_{\text {hitung }}=6,868$ dan $\mathrm{t}_{\text {tabel }}=\mathrm{t}_{(1-\alpha ; \mathrm{n}-\mathrm{k}-1)}=\mathrm{t}_{(0,5 ; 229)}=0,674$. Karena $\mathrm{t}_{\text {hitung }}>\mathrm{t}_{\text {tabel }}$ maka Tolak $\mathrm{H}_{0}$ yang artinya koofisien jalur $\mathrm{p}_{21}$ signifikan. Sehingga koofisien jalur $\mathrm{p}_{21}$ secara stastistik bermakna.

Hasil penelitian ini sejalan dengan pendapat arifin bahwa hasil belajar siswa mempunyai beberapa fungsi yaitu sebagai indikator kualitas dan kuantitas pengetahuan yang telah dikuasai anak didik dan sebagai bahan informasi kepada siswa untuk mendorong siswa meningkatkan ilmu pengetahuan yang telah mereka miliki. Salah satu usaha yang dilakukan adalah dengan peranan siswa untuk memiliki konsep diri dan motivasi berprestasi selama proses pembelajaran sehingga hasil belajar matematikanya meningkat.

Untuk dapat mengetahui koofisien jalur mana yang lebih besar,maka dilakukan pengujian perbedaan besarnya koofisien jalur. Dari pengujian diperoleh $t_{\text {hitung }}=-0,1065$ dan $\mathrm{t}_{\text {tabel }}=\mathrm{t}_{(1-\alpha, \mathrm{n}-\mathrm{k}-1)}=\mathrm{t}_{(0,95,229)}=1,645$ dengan kriteria pengujian tolak $\mathrm{H}_{0}$ jika $\mathrm{t}_{\text {hitung }}>\mathrm{t}_{\text {tabel(n-k- }}$ 1), maka dapat disimpulkan bahwa besar koofisien jalur dari konsep diri siswa terhadap hasil belajar matematika (Y) dianggap sama dengan besar koofisien jalur dari motivasi berprestasi siswa $\left(\mathrm{X}_{2}\right)$ terhadap hasil belajar matematika siswa $(\mathrm{Y})$, walaupun koofisien jalur $\mathrm{X}_{2}$ terhadap $\mathrm{Y}$ lebih besar dibandingkan dengan besar koofisien jalur $\mathrm{X}_{1}$ terhadap $\mathrm{Y}$.

Konsep diri yang positif merupakan daya penggerak bagi siswa untuk mengusahakan kemajuan belajar, sehingga siswa akan memandang dirinya memiliki kemampuan untuk dapat mencapai cita-cita. Sedangkan Motivasi berprestasi adalah dimana seseorang cenderung berjuang untuk mencapai sukses atau memilih suatu kegiatan yang berorientasi untuk tujuan sukses atau gagal.

Dalam menghadapi pelajaran matematika yang dianggap sebagian siswa adalah mata pelajaran yang sulit, dibutuhkan konsep diri yang positif bahwa ia mampu dalam menyelesaikan permasalahan-permasalahan dalam matematika yang akan mampu meningkatkan motivasi dalam diri siswa untuk berprestasi dalam belajar. Sehingga pada akhirnya nanti, siswa dapat memandang seluruh tugas sebagai hal yang mudah untuk diselesaikan dan lebih jauh lagi akan meningkatkan motivasi dalam diri siswa.

Dengan demikian motivasi berprestasi bersumber dari dalam individu dan bukan dari diri orang lain, sehingga dapat tercapai suatu keberhasilan dalam belajar. Motivasi berprestasi sangat penting perannya dalam pencapaian suatu keberhasilan karena tercapai suatu keberhasilan seseorang disebabkan adanya motivasi dari diri sendiri sehingga tercapai hasil belajar yang baik.

Kehadiran faktor-faktor psikologis dalam belajar memberikan kontibusi yang berarti pada pencapaian hasil belajar yang lebih baik. Faktor-faktor psikologis ini dapat dipandang sebagai cara-cara berfungsinya pikiran manusia dalam hubungannya dengan 
pemahaman materi pelajaran. Dalam penelitian ini yang dimaksud faktor-faktor psikologis adalah konsep diri dan motivasi berprestasi.

Proses belajar mengajar akan berhasil dengan baik, jika didukung oleh faktorfaktor psikologis dari siswa. Salah satu faktor psikologis yang memberikan kontribusi besar adalah motivasi berprestasi. Motivasi berprestasi dapat dimiliki oleh siswa dapat lahir dari konsep diri yang ada dalam diri siswa.

\section{Pengaruh tidak langsung konsep diri siswa terhadap hasil belajar matematika melalui motivasi berprestasi}

Konsep diri memiliki peranan penting dalam menentukan perilaku individu. Bagaimana individu memandang dirinya, akan tampak dari seluruh perilakunya. Dengan kata lain, perilaku individu akan sesuai dengan cara individu memandang dirinya sendiri. Apabila individu memandang dirinya sebagai orang yang tidak cukup mempunyai kemampuan untuk melakukan suatu tugas, amak seluruh perilakunya akan menunjukan ketidakmampuan tersebut.

Konsep diri merupakan bagaimana seseorang berpikir mengenai dirinya sendiri. Apabila individu percaya bahwa dirinya mampu untuk melakukan sesuatu maka individu akan termotivasi untuk melakukan hal tersebut sehingga akan mempengaruhi hasil belajar matematika nya.

Komponen konsep diri terbentuk atas dua komponen yaitu komponen kognitif dan komponen afektif.

a. Komponen kognitif

Merupakan pengetahuan individu tentang keadaan dirinya, misalnya saya anak bodoh atau saya anak nakal. Jadi komponen kognitif merupakan penjelasan dari "siapa saya" yang akan memberi gambaran tentang diri saya. Gambaran diri tersebut akan membentuk citra diri.

b. Komponen afektif

Merupakan penilaian individu tentang diri. Penilaian tersebut akan membentuk pencerminan terhadap diri. Penilaian tersebut akan membentuk penerimaan diri, serta harga diri individu.

Dari penjelasan diatas dapat dikatakan bahwa, komponen kognitif merupakan data yang bersifat objektif dan komponen afektif merupakan data yang bersifat subjektif. Apabila kita membicarakan masalah tentang konsep diri maka kita tidak akan terlepas membicarakan masalah gambaran diri, citra diri, penilaian diri dan tingkah laku. Setiap tindakan manusia selalu didorong oleh faktor-faktor tertentu sehinggga terjadi tingkah laku atau perbuatan. Faktor pendorong ini di sebut motif. Motif adalah suatu alasan atau dorongan yang menyebabkan individu berbuat sesuatu atau melakukan tindakan tertentu. Motif-motif tersebut pada saat tertentu akan menjadi aktif apabila kebutuhan untuk mencapai tujuan sangat dirasakan

Motivasi berprestasi siswa dapat ditimbulkan dengan cara memberikan stimulus yang berpangkal pada kebutuhan siswa. Siswa yang memiliki motivasi selalu unggul dan berprestasi dalam proses belajar mengajar tidak merasa takut gagal melainkan selalu berusaha untuk memperbaiki kesalahannya sehingga dapat meningkatkan hasil belajar matematikanya.

Berdasarkan penjelasan diatas, dapat disimpulkan bahwa konsep diri secara tidak langsung dapat mempengaruhi hasil belajar siswa terlebih dahulu menimbulkan rasa motivasi untuk berprestasi sehingga mencapai hasil belajar matematika yang baik. 


\section{PENUTUP}

\section{Kesimpulan}

Penelitian ini adalah usaha untuk memperoleh informasi tentang ada atau tidaknya pengaruh konsep diri dan motivasi berprestasi siswa dalam proses pembelajaran terhadap hasil belajar matematika siswa.

Dari uraian teoritis, sampai kepada hasil penelitian maka kini dapat ditarik kesimpulan, yaitu:

1. Terdapat pengaruh langsung konsep diri terhadap hasil belajar matematika siswa.

2. Terdapat pengaruh langsung motivasi berprestasi terhadap hasil belajar matematika siswa.

3. Terdapat pengaruh langsung konsep diri dan motivasi berprestasi siswa.

4. Terdapat pengaruh tidak langsung konsep diri terhadap hasil belajar melalui motivasi berprestasi.

\section{Saran}

Dari kesimpulan yang telah dikemukakan, maka untuk meningkatkan hasil belajar siswa ada beberapa saran antara lain :

\section{Untuk Guru}

a. Dalam meningkatkan hasil belajar siswa khususnya pada mata pelajaran matematika, maka guru yang mengajar matematika diharapkan memiliki pemahaman yang benar akan kondisi anak didiknya. Dalam hal ini guru matematika harus memberikan fungsi tambahan tidak hanya memberikan ilmu tetapi perhatian khusus sehingga guru matematika dapat menjadi seorang konselor yang baik, menjadi orang yang dapat dipercaya oleh anak didiknya untuk menjadi tempat berbagi dalam menghadapi masalah-masalah yang dihadapi selama proses pembelajaran dikelas

b. Guru matematika hendaknya saat mengajar mempergunakan metode yang bervariasi dan kreatif sehingga dapat menumbuhkan motivasi siswa untuk berprestasi dalam kelas dan aktiv dalam kegiatan pembelajaran.

c. Guru matematika hendaknya memiliki program pengajaran dan persiapan yang baik sebelum mengajar sehingga proses pembelajaran dapat berlangsung dengan lancar.

\section{Untuk Sekolah}

a. Untuk meningkatkan hasil belajar siswa diharapkan pihak sekolah mengadakan pelatihan atau kegiatan yang berhubungan dengan " bagaimana meningkatkan konsep diri dan motivasi berprestasi siswa selama belajar"

b. Sekolah sebagai lembaga pendidikan formal secara aktiv dan langsung harus memperhatikan sarana dan prasarana yang diperlukan untuk menunjang proses belajar dan mengajar matematika

\section{Untuk Siswa}

a. Bagi siswa yang merasa dirinya kurang maksimal dalam mencapai keberhasilan dalam belajar dibidang matematika agar jangan rendah diri dan putus asa, melainkan tetap menpunyai pandangan positif terhadap kemampuan dirinya. Dengan demikian siswa akan dapat melewati kesulitan-kesulitan dalam pembelajaran matematika.

b. Untuk memperoleh hasil belajar matematika yang tinggi diperlukan konsep diri yang tinggi dari siswa saat belajar dan motivasi yang tinggi untuk berprestasi. Hal ini telah dibuktikan dengan hasil penelitian diatas. Meningkatkan hasil belajar siswa khususnya dalam mata pelajaran matematika hendaknya ditunjang dengan 
pandangan positif siswa terhadap kemampuan dirinya dan motivasi untuk terus berprestasi.

c. Banyak faktor yang dapat meningkatkan hasil belajar matematika siswa, diantaranya adalah konsep diri yang ada dalam diri siswa. Untuk itu diperlukan siswa-siswa yang memiliki pandangan dan penghargaan yang tinggi akan kemampuan dirinya,khususnya dalam menyelesaikan masalah-masalah dalam metematika.

d. Motivasi untuk berprestasi siswa dalam proses pembelajaran dikelas merupakan suatu dorongan yang kuat untuk mendorong siswa mengungguli, berprestasi sehubungan dengan seperangkat standard an usaha untuk mendapat keberhasilan dalam matematika.

e. Bagi siswa yang sudah maksimal dalam mencapai keberhasilannya dalam belajar diharapkan terus mempertahankan dan meningkatkannya dikemudian hari sehingga dapat terus mengukir prestasi dalam belajar.

4. Diharapkan ada penelitian lanjutan dengan subyek yang lebih luas mengenai konsep diri dan motivasi berprestasi siswa yang memiliki pengaruh terhadap hasil belajar matematika siswa.

\section{DAFTAR PUSTAKA}

Arikunto, Suharsini. 1999. Dasar - dasar Evaluasi Pendidikan. Jakarta: Bumi Aksara.

Arikunto, Suharsini. 2001. Prosedur Penelitian Suatu Praktek. Jakarta: PT. Rineka Cipta.

Djiwandono, Sri Esti Wuryani. 2008. Psikologi Pendidikan Jakarta: Grasindo.

Gunarsa, S.D dan Gunarsa, Ny. S.D. 1999. Psikologi Perkembangan Anak dan Remaja. Jakarta: PT. Gunung Mulia.

Herman Hudoyo. 1988. Mengajar Belajar Matematika. Jakarta: Depdikbud.

Hamalik. O. 2001. Proses Belajar Mengajar. Cetakan ke Satu, Jakarta: Bumi Aksara.

Purwanto, Ngalim. 2002. Ilmu Pendidikan: Teoritis dan Praktis. Bandung: Rosda Karya.

Purwanto, Ngalim. 2007. Psikologi Pendidikan. Bandung: PT. Remaja Rusda Karya.

Pujijogyanti, Clara R. 1999. Konsep Diri Dalam Pendidikan. Jakarta: Penerbit Arman.

Rustiyah, N.K dan Farida Purnomo. 2002. Teori - teori Belajar. Jakarta: Nasco.

Riduwan. 2003. Dasar-Dasar Statistik. Cetakan ke-2. Bandung: Alfabeta.

Sudjana, Nana. 2005. Metode Statistika. Bandung: Penerbit Tarsito.

Sudjana, Nana. 2000. Dasar-Dasar Proses Mengajar. Sinar Baru: Aglesindo Bandung.

Slameto, 1999. Belajar dan Faktor-Faktor Mempengaruhi. Jakarta: Bhineka Cipta.

Sugiyono. 2007. Metode Penelitian Kuantitatif, Kualitatif dan R \& D. Bandung: Penerbit Alfabeta.

Winkel, W.S. 1999. Psikologi Pendidikan dan Evaluasi Pendidikan. Jakarta: Gramedia. 